\title{
Ex vivo model of rabbit intestinal epithelium applied to the study of colonization by enteroaggregative Escherichia coli
}

\author{
Ricardo Luís Lopes BRAGA, Ana Claudia Machado PEREIRA, Paula Azevedo dos SANTOS, \\ Angela Corrêa FREITAS-ALMEIDA and Ana Cláudia de Paula ROSA
}

Received 7/10/2016

\begin{abstract}
Background - The diarrheal syndrome is considered a serious public health problem all over the world and is considered a major cause of morbidity and mortality in developing countries. The high incidence of enteroaggregative Escherichia coli in diarrheal syndromes classified as an emerging pathogen of gastrointestinal infections. After decades of study, your pathogenesis remains uncertain and has been investigated mainly using in vitro models of adhesion in cellular lines. Objective - The present study investigated the interaction of enteroaggregative Escherichia coli strains isolated from childhood diarrhea with rabbit ileal and colonic mucosa ex vivo, using the in vitro organ culture model. Methods - The in vitro adhesion assays using cultured tissue were performed with the strains co-incubated with intestinal fragments of ileum and colon over a period of 6 hours. Each strain was tested with three intestinal fragments for each region. The fragments were analysed by scanning electron microscopy. Results - Through scanning electron microscopy we observed that all strains adhered to rabbit ileal and colonic mucosa, with the typical aggregative adherence pattern of "stacked bricks" on the epithelium. However, the highest degree of adherence was observed on colonic mucosa. Threadlike structures were found in greater numbers in the ileum compared to the colon. Conclusion - These data showed that enteroaggregative Escherichia coli may have a high tropism for the human colon, which was ratified by the higher degree of adherence on the rabbit colonic mucosa. Finally, data indicated that in vitro organ culture of intestinal mucosa from rabbit may be used to elucidate the enteroaggregative Escherichia coli pathogenesis.
\end{abstract}

HEADINGS - Escherichia coli. Intestinal mucosa, ultrastructure. Organ culture techniques. Rabbits. Scanning electron microscopy.

\section{INTRODUCTION}

EAEC is an emerging diarrheal pathotype described in the diarrheagenic $E$. coli group (DEC) and has been characterized by the aggregative adherence (AA) pattern where bacteria adhered to the HEp-2 cells (line derived from human laryngeal carcinoma) in a similar arrangement of "stacked bricks"(17).

Associated with cases of acute and persistent diarrheal disease EAEC affect children and adults in all regions of the world, patients in developing countries infected with human immunodeficiency virus (HIV), travelers from industrialized countries visiting less developed regions and residents of industrialized countries with foodborne gastroenteritis outbreaks ${ }^{(6)}$.

Several putative virulence factors are involved in the pathogenesis, which remains uncertain due to it is complexity. It was suggested a three-stage model: i) adhesion of bacteria to the intestinal mucosa; ii) mucus secretion stimulated by bacteria forming a biofilm, which could favor the persistent colonization; and iii) production of toxins and inflammatory response involved in the damage to the intestinal mucosa ${ }^{(11)}$.

Most of the knowledge about the interactions of bacteria and intestinal organs has been obtained from studies with human biopsies collected during surgical intervention or from samples obtained from elderly individuals at autopsy ${ }^{(8)}$. In order to elu- cidate the mechanisms of EAEC pathogenesis, models of study in organ culture in vitro (IVOC) from intestinal fragments from different portions of the small or/and large intestines of pediatric patients $^{(1,2,10,18,23)}$ and of adults ${ }^{(2,15,23)}$ have been developed. Here we propose a more feasible animal study model in order to apply our understanding on the pathogenesis mechanism of EAEC strains.

\section{METHODS}

\section{Bacterial strains}

EAEC strains were isolated from the faeces of children under two years of age with acute diarrhea coming from the urban area of Rio de Janeiro, Brazil. Diarrhea was defined as the occurrence of one or more elimination of liquid faeces in a period of 24 hours $^{(20)}$. As a positive control, the prototype strain EAEC 042, isolated from children with diarrhea in outbreak in Peru ${ }^{(16)}$ was used to infect the ileal and colonic fragments. As a negative control, non-infected intestinal fragments were used. The EAEC strains were previously characterised by DNA hybridization probe ${ }^{(3)}$ or by polymerase chain reaction $(\mathrm{PCR})^{(21)}$ for putative virulence factors of $\mathrm{EAEC}^{(7,20)}$. Adhesion assays in intestinal cell lines after 6 hours of incubation was used to characterize the aggregative pattern (Table 1). All strains were stored at $-70^{\circ} \mathrm{C}$ in Trypticase Soy Broth (TSB, Merck) supplemented with 20\% glycerol. 
TABLE 1. Enteroaggregative Escherichia coli (EAEC) and prototype strains and their serotypes, phylogenetic groups, virulence factors and adherence patterns

\begin{tabular}{|c|c|c|c|c|c|}
\hline \multirow{2}{*}{ Strains } & \multirow{2}{*}{ Serotype a } & \multirow{2}{*}{ Phylogenetic Group } & \multirow{2}{*}{ Virulence factors ${ }^{b}$} & \multicolumn{2}{|c|}{ Adherence Patterns ${ }^{c}$} \\
\hline & & & & Сaco-2 & T84 \\
\hline $\mathrm{H} 92 / 3$ & O86:H18 & $\mathrm{D}$ & $\mathrm{pAA}^{*}, \operatorname{aggA}, \operatorname{agg} R$, aap$, f y u A, i r p 2, p i c$ & AA & AA \\
\hline $\mathrm{I} 34 / 4$ & O111:H21 & $\mathrm{D}$ & pAA*, $\operatorname{agg} 3 A, \operatorname{agg} R, \operatorname{aap}, \operatorname{ast} A, f y u A, \operatorname{irp} 2$, pet, pic & AA & $\mathrm{AA}$ \\
\hline $\mathrm{I} 49 / 3$ & $\mathrm{O} 26: \mathrm{H} 27$ & A & $\mathrm{pAA}^{*}, \operatorname{agg} 3 \mathrm{~A}, \operatorname{agg} R$, aap, ast $\mathrm{A}$, irp2, pet, pic & NA & AA \\
\hline 042 & $\mathrm{O} 44: \mathrm{H} 18$ & $\mathrm{D}$ & $\mathrm{pAA}^{*}$, aafA, aggR, aap, ast $A$, fyuA, irp2, pet, pic & AA & AA \\
\hline
\end{tabular}

${ }^{a} \mathrm{O}$, somatic antigen polysaccharide; $\mathrm{H}$, flagellar antigen. ${ }^{\mathrm{b}} \mathrm{pAA}$, aggregative adherence plasmid; agg $A$, aggregative adherence fimbriae I; agg $R$, transcriptional regulator; aap, dispersin; fyuA and $i r p 2$, genes involved in iron caption; pic, protein involved in colonization; agg $3 A$, aggregative adherence fimbriae III; ast $A$, thermostable protein; pet, plasmid enconded toxin; aafA, aggregative adherence fimbriae II. *detection by hybridization with DNA probe. ${ }^{c}$ AA, aggregative adherence; NA, non-adherence.

\section{Rabbit selection and preparation}

New Zealand white male rabbits $(1.0-1.5 \mathrm{~kg})$ supplied by bioterium of Institute Vital Brazil (Rio de Janeiro, RJ) were used to obtain intestinal tissue for experiments. Previously, rabbit faeces were collected, seeded in TSA (Difco lab), Mac Conkey agar (Merck) and CLED agar (Merck) and incubated at $37^{\circ} \mathrm{C}$ for a period of 24 hours to certify that the animals were not infected with enteropathogens. Samples tested did not show growth of microorganisms. The rabbits were subjected to fasting for 24 hours before experimental procedures. They were observed for any gastrointestinal manifestations and were used only if found to be symptom-free.

\section{Rabbit in vitro organ culture adhesion assay}

To obtain intestine fragments of ileum and colon, the animals were anesthetized and euthanized by intravenous application Tiopentax (sodium thiopental, $10 \mathrm{mg} / \mathrm{kg}$, Cristália, São Paulo, Brazil). Then the trichotomy of the abdominal region was performed and, subsequently, asepsis of the incision site with iodized alcohol. The gastrointestinal tract was exteriorized through a ventral midline incision and the mucosa was washed with saline and it was made identification of anatomical sites of the intestinal tract.

The adhesion assays were performed as previously described $^{(10,14)}$ with some modifications. Briefly, 2- to 3- $\mathrm{mm}^{2}$ fragments of tissues were oriented mucosal surface upward on sterile foam squares placed into a 6-well plate (about 35-mm-diameter). The foam was saturated with Dulbecco's Modified Eagle's Medium (DMEM; Gibco) supplemented with 10\% fetal calf serum (FCS) and $0.5 \%$ D-mannose. The level of DMEM medium was adjusted to cover the biopsy specimens with a thin film of medium by capillary action.

Bacterial strains were inoculated in $3 \mathrm{~mL}$ of TSB (Merck) and incubated for 18 hours at $37^{\circ} \mathrm{C}$ and aliquots of $50 \mu \mathrm{L}$ standardized bacterial suspensions (approximately $10^{7} \mathrm{CFU} \mathrm{mL}^{-1}$ ) was inoculated on the mucosal surface of the fragments and the 6-weel tissue culture plate was then incubated at $37^{\circ} \mathrm{C}$ in an atmosphere with $5 \% \mathrm{CO}_{2}$ for 6 hours. The culture medium was changed completely every 2 hours to maintain $\mathrm{pH}$ and nutrient levels, without reinoculation with the bacterial culture. After these incubation periods, biopsy samples were washed and prepared for scanning electron microscopy (SEM). EAEC strains were tested with three intestinal fragments of each intestinal region.

\section{Tissue processing}

The fragments collected were washed with $0.9 \%$ sterile saline and $0.1 \mathrm{M}$ sodium cacodylate buffer, $\mathrm{pH} 7.2$ and fixed with $2.5 \%$ glutaraldehyde and $2 \%$ formaldehyde in $0.1 \mathrm{M}$ sodium cacodylate buffer, pH 7.2. Later, the fragments were washed three times in $0.1 \mathrm{M}$ sodium cacodylate buffer, $\mathrm{pH} 7.2$ and dehydrated through a graded series of ethanol solutions $(30 \%, 50 \%, 70 \%, 90 \%$ and $100 \%)$. Then, the fragments were transferred to baskets and subjected to the drying apparatus chambre (Bal-Tec CPD 030) by the critical point of carbon dioxide method, to be performed replacing absolute ethanol by carbon dioxide. Subsequently, specimens were mounted on stubs with the vili upward with the aid of a stereoscopic microscope, coated with gold in sputter (Balzers Union FL-9496) to become conductors. The observations were performed in the Ultrastructure Cellular Laboratory Hertha Meyer of the Universidade Federal do Rio de Janeiro (LCU, UFRJ) in scanning electron microscope (QUANTA 250, FEI) operating at $15 \mathrm{Kv}$.

\section{Ethical considerations}

The study protocol used was approved by Ethic Committee (Comitê de Ética Para o Cuidado e Uso de Animais Experimentais) of Biology Institute Roberto Alcântara Gomes of Universidade do Estado do Rio de Janeiro (UERJ) n CEA/236/2008.

\section{RESULTS}

\section{EAEC strains interaction with ileal mucosa fragments}

Analysis by SEM of non-infected ileum showed that fragments presented the mucosa preserved (Figure 1A). The prototype EAEC 042 strain adhered to the ileal mucosa in the aggregative characteristic pattern of "stacked bricks" (Figure 1C). 


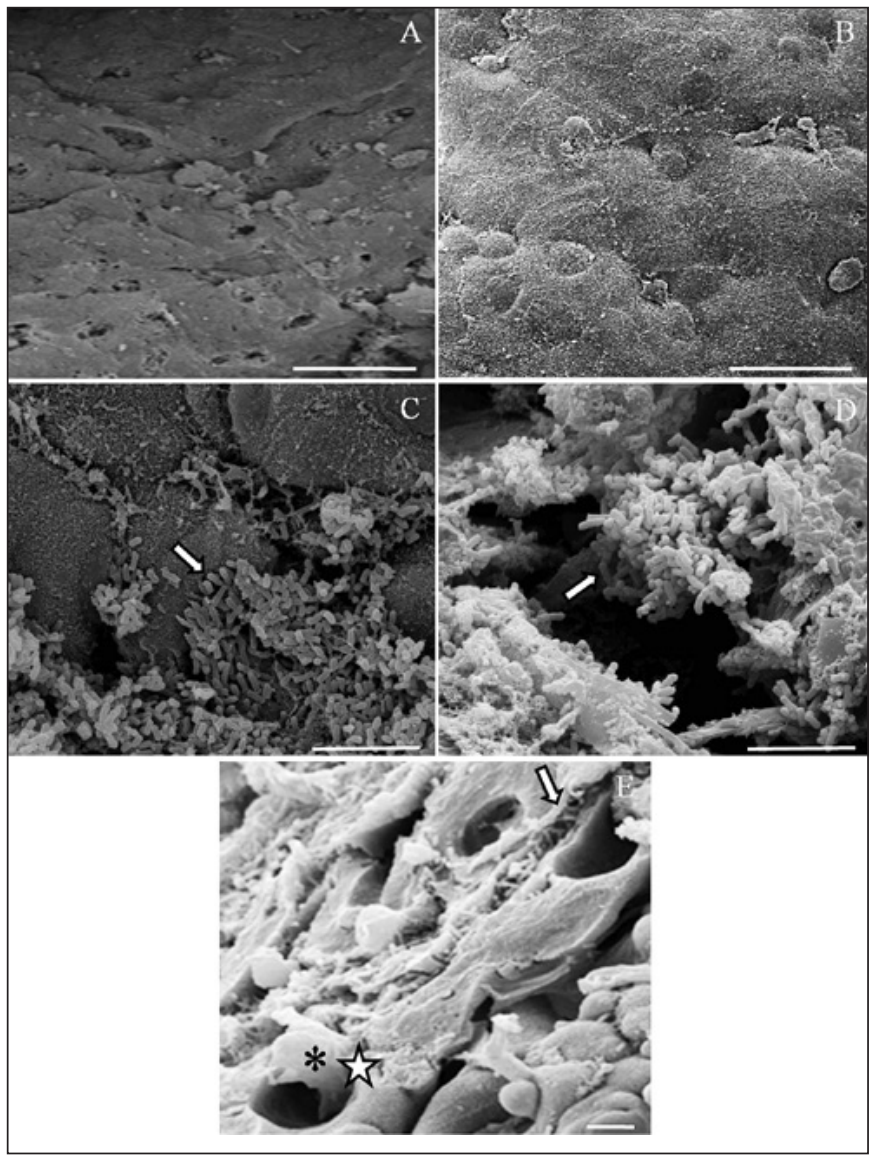

FIGURE 1. A) (1000X; bar- $10 \mu \mathrm{m}), \mathrm{B})(1000 \mathrm{X}$; bar- $10 \mu \mathrm{m}), \mathrm{C})(5000 \mathrm{X}$; bar-10 $\mu \mathrm{m})$, D) (5000X; bar-10 $\mu \mathrm{m})$ and E) (1000X; bar- $5 \mu \mathrm{m})$. Micrograph of the intestinal rabbit mucosa ex vivo, after 6 hours of incubation, observed by scanning electron microscopy. Mucosa preserved on the ileum (A) and on the colon (B) epithelium non-infected. Infected tissue with EAEC 042 showed large bacterial aggregates in a "stacked bricks" pattern $(\rightarrow)$ adhered to the epithelium of the ileum $(C)$ or forming a thick three-dimensional biofilms on the colon (D). The opened and dilated crypts (负) with discharge of mucus (*) showed in the colon (E).

The intestinal fragments infected with the EAEC strains revealed bacterial aggregates as observed in cell lines Caco-2, cell line of human colorectal adenocarcinoma with phenotypic characteristics of the ileum, adhered directly on the epithelium with isolated points of mucus produced above the mucosa (Figures 2A and 2C). Although the I49/3 strain did not display the standard AA in Caco-2, this was presented in IVOC rabbit model.

Threadlike structures (Figure 2E) were found in all strains, except the positive control, in greater numbers in the ileum compared to colon fragments apparently mediating bacteria-bacteria and bacteria-epithelium interactions.

\section{EAEC strains interaction with colonic mucosa fragments}

Analysis by SEM of the colonic fragments non-infected showed mucosa preserved (Figure 1B). The prototype EAEC 042 strain adhered to the colonic mucosa in the aggregative characteristic pattern of "stacked bricks" and were able to form a thick threedimensional biofilm (Figure 1D). Also it was observed the opening of colonic crypts with discharge of mucus (Figure 1E).

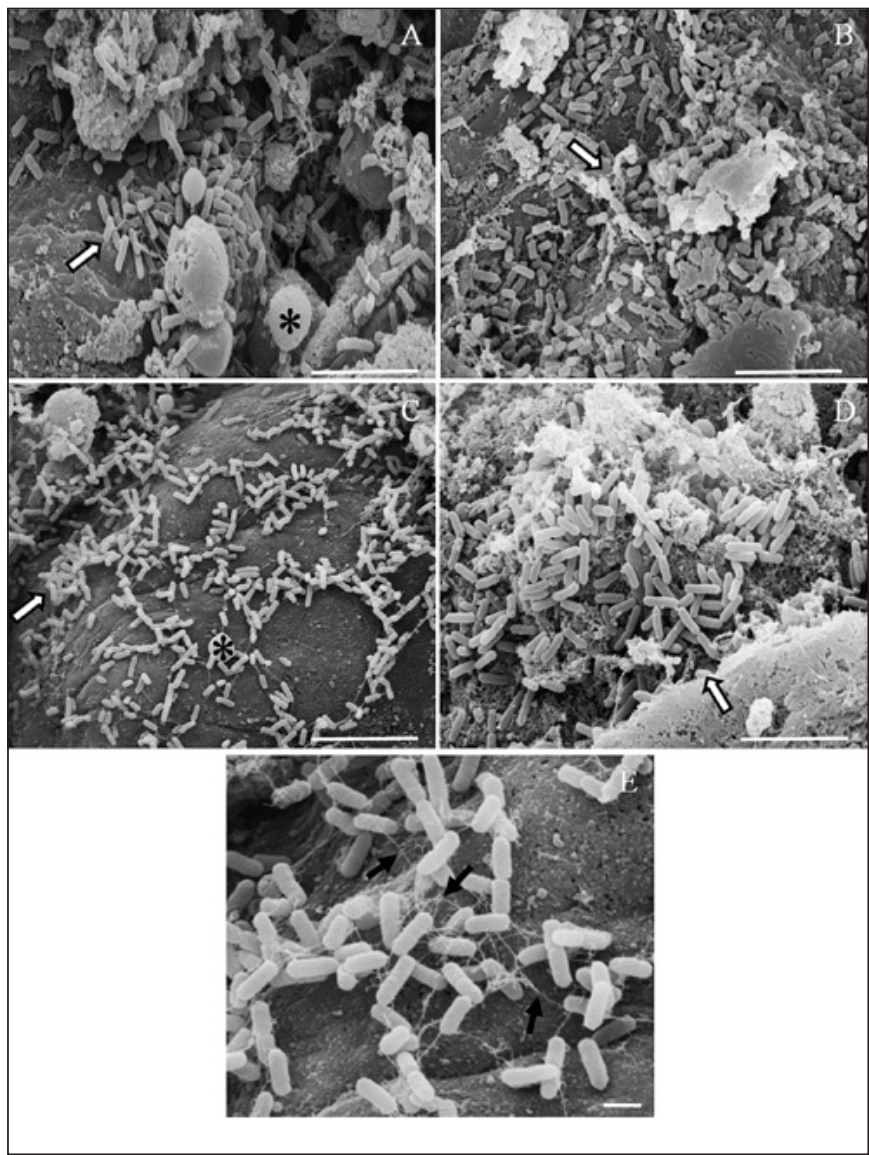

FIGURE 2. A) (3500X; bar- $10 \mu \mathrm{m})$, B) (3500X; bar- $10 \mu \mathrm{m}), \mathrm{C})$

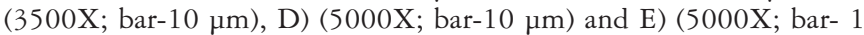
$\mu \mathrm{m})$. Micrograph of the EAEC strains interaction with intestinal rabbit mucosa ex vivo, after 6 hours of incubation, observed by scanning electron microscopy. Interaction with I34/4 strain with bacterial aggregates $(\rightarrow)$ and isolated points of mucus $(*)$ above the ileum $(A)$ and colonic (B) epithelium. Interaction with I $49 / 3$ strain with bacterial aggregates $(\rightarrow)$ and isolated points of mucus (*) directly on the ileum epithelium (C) and intense adherence with large bacterial aggregates on the colonic epithelium (D). Ileal mucosa showed threadlike structures $(\rightarrow)$ mediating the link between bacteria-bacteria and bacteria-cell (E).

The intestinal fragments infected with the EAEC strains revealed intense adherence with large bacterial aggregates as observed in cell lines T84, cell line of human colon carcinoma with phenotypic characteristics of the colon, adhered directly on the colonic epithelium (Figures 2B and 2D).

The analysis of adherent bacteria by SEM revealed the highest number of bacteria adherent in the colon fragments when compared to the ileum fragments.

\section{DISCUSSION}

Since EAEC has been isolated from several patients suffering from acute or chronic diarrhea in a number of regions of the world and from various socioeconomic strata your research is also challenging. In addition to this the genetic heterogeneity of the pathotype which considerably complicates our understanding of the pathogenicity, the therapeutic approaches and international surveillance ${ }^{(11)}$. 
The study of EAEC in several models, such as in the in vitro/in vivo assays in animals ${ }^{(22,23)}$, in the in vitro organ culture in cellular lines $^{(1,9,18)}$ and with human intestinal fragments ${ }^{(1,2,10,15,18,23)}$ has been widely used by more faithfully mimic the EAEC action in the host.

Thus, IVOC represents ideally a good model for study of the bacterial pathogenesis in intestinal explants which remain structurally intact for periods of hours in culture ${ }^{(10)}$. This technique has utilized human tissue biopsies, tissue fragments extracted during colonoscopy and even of animals.

In the present study, the EAEC strains challenged in the ex vivo rabbit model were able to adhere to both intestinal fragments, ileum and colon, in the analysis by SEM, and they formed bacterial aggregates with a similar pattern of "stacked bricks" adhered directly on the epithelium with isolated points of mucus in some strains. Still, it was possible to infer a higher number of bacteria adherent to colon fragments when compared to the ileum fragments.

Studies conducted by Yamamoto et al. ${ }^{(23)}$ and Nataro et al. ${ }^{(18)}$ are consistent with ours. Yamamoto et al. ${ }^{(23)}$ showed that the EAEC strain 0127:H2 exhibited lower levels of adherence in the jejunal and ileal mucosa and higher levels of adherence to colonic mucosa fixed in formalin. Already Nataro et al. ${ }^{(18)}$ from jejunal, ileum and colon mucosa explants obtained from three pediatric patients revealed that the number of bacteria adherent to colon specimens was significantly higher than the adhering bacteria to mucosal samples of small intestine.

The adhesion of EAEC to the large intestine but not to the mucosa of human small intestine, not only demonstrates that EAEC possess properties enteroadherent, but also suggests that this may be the preferred site of colonization of this pathotype. Still, the lack of adhesion to ileal mucosa could be due to a lack of receptors for EAEC ${ }^{(15)}$. Additionally, Kang et al. ${ }^{(13)}$ suggested that the degree of cell differentiation and maturation may also affect the receptor concentration and such differences in receptor expression may have an important role in determining the EAEC binding site.

Andrade et al. ${ }^{(2)}$ analyzing the interaction of EAEC strains with pediatric and adults human intestinal fragments of ileum and colon, demonstrated that all EAEC strains adhered to both regions evaluated on a layer of thick mucus and sometimes directly to the mucosa. In all cases in which the strains were adherent to the mucosa in significant numbers, they did into aggregates with the pattern of "stacked bricks" similar to that observed in HEp-2 cell culture.

In the present study threadlike structures were observed in all strains, except the positive control, in greater numbers in the ileum compared to colon fragments. The aag and agg3 genes encode $\mathrm{AAF} / \mathrm{I}$ and $\mathrm{AAF} / \mathrm{III}$, respectively, and are long and flexible fimbriae which are involved in the cohesion of bacterial aggregates and binding with intestinal cells ${ }^{(4,5)}$. This may explain why these structures were observed in our strains and was not observed in EAEC 042 strain, which has a short and rigid fimbriae.

Our results are consistent with studies conducted by Andrade et al. (2) that observed non-characterized fimbrial structures on bacterial surface interacted with the human ileum fragments, apparently mediating bacteria-bacteria and bacteria-cell interactions. Pereira et al. ${ }^{(19)}$ observed that bacterial aggregates forming biofilms in abiotic surface were mediated by non-bundle forming, flexible pili and that the increased adherence might be mediated by putative $\mathrm{F}$ pili expressed by EAEC strains. The I18/2 strain not possess any of the genes described for the fimbriae AAFs. Possibly the visualized threadlike structures could be a novel aggregative adherence fimbria variant (AAF/V) as suggested recently by Jonsson et al. ${ }^{(12)}$. Further investigation is needed to better understand the main role of these structures in the pathogenesis of these heterogeneous pathotype, once that a wide diversity of adhesive structures include uncharacterized nonfimbrial and fimbrial adhesins.

In conclusion, all challenged EAEC strains adhered to both intestinal fragments, with the highest tropism in the colon, ratifying the use of the IVOC model as a tool for studying the pathogenesis of this pathotype. Finally, the present study is pioneer in the use of rabbit IVOC to evaluate the pathogenic role of EAEC strains.

\section{Authors' contributions}

Braga RLL: survey execution, writing of text. Pereira ACM: survey execution; reviewing of text. Santos PA: survey execution. Freitas-Almeida AC: reviewing of text. Rosa ACP: project coordinator, reviewing of text.

Braga RLL, Pereira ACM, Santos PA, Freitas-Almeida AC, Rosa ACP. Modelo ex vivo de epitélio intestinal de coelho aplicado ao estudo de colonização por Escherichia coli enteroagregativa. Arq Gastroenterol. 2017;54(2):130-4.

RESUMO - Contexto - A síndrome diarréica é considerada um grave problema de saúde pública em todo o mundo e é considerada uma das principais causas de morbidade e mortalidade nos países em desenvolvimento. A elevada incidência de Escherichia coli enteroagregativa nas síndromes diarreicas a classificou como um patógeno emergente de infecções gastrintestinais. Depois de décadas de estudo, sua patogênese ainda é incerta e tem sido investigada usando principalmente modelos in vitro de adesão em linhagens celulares. Objetivo - O presente estudo investigou a interação de cepas de Escherichia coli enteroagregativa isoladas de diarreia infantil com mucosa ileal e colônica de coelho ex vivo, utilizando o modelo de cultura de órgão in vitro. Métodos - Os ensaios de adesão in vitro utilizando tecido cultivado foram realizados com as cepas co-incubadas com fragmentos intestinais de íleo e de cólon durante um período de 6 horas. Cada cepa foi testada em três fragmentos intestinais para cada região. Os fragmentos foram analisados por microscopia eletrônica de varredura. Resultados - Através da microscopia eletrônica de varredura observamos que todas as cepas aderiram a mucosa ileal e colônica de coelho, com o padrão de aderência agregativo típico de "tijolos empilhados" no epitélio. Entretanto, o maior grau de adesão foi observado na mucosa do cólon. Estruturas filiformes foram encontradas em maior número no íleo em comparação com o cólon. Conclusão - Esses dados mostraram que Escherichia coli enteroagregativa pode ter um maior tropismo para o cólon humano, o que foi ratificado pelo maior grau de aderência na mucosa do cólon de coelho. Finalmente, os dados indicaram que a cultura de órgão in vitro da mucosa intestinal de coelho pode ser utilizado para elucidar a patogênese de Escherichia coli enteroagregativa.

DESCRITORES - Escherichia coli. Mucosa intestinal, ultraestrutura. Técnicas de cultura de órgãos. Coelhos. Microscopia eletrônica de varredura. 


\section{REFERENCES}

1. Abe CM, Knutton S, Pedroso MZ, Freymüller E, Gomes TAT. An enteroaggregative Escherichia coli strain of serotype O111:H12 damages and invades cultured T84 cells and human colonic mucosa. FEMS Microbiol Lett. 2001;203: 199-205.

2. Andrade JAB, Freymüller E, Fagundes-Neto U. Adherence of enteroaggregative Escherichia coli to ileal and colonic mucosa: an in vitro study utilizing the scanning electron microscopy. Arq Gastroenterol. 2011;48:199-204.

3. Baudry B, Savarino SJ, Vial P, Kaper JB, Levine MM. A sensitive and specific DNA probe to identify enteroaggregative Escherichia coli, a recently discovered diarrheal pathogen. J Infect Dis. 1990;161:1249-51.

4. Bernier C, Gounon P, Le Bouguénec C. Identification of an aggregative adhesion fimbria (AAF) type III-encoding operon in enteroaggregative Escherichia coli as a sensitive probe for detecting the AAF-encoding operon family. Infect Immun. 2002; 70:4302-11.

5. Czeczulin JR, Balepur S, Hicks S, Phillips A, Hall R, Kothary MH, et al. Aggregative adherence fimbria II, a second fimbrial antigen mediating aggregative adherence in enteroaggregative Escherichia coli. Infect Immun. 1997;65: 4135-45.

6. Estrada-Garcia T, Navarro-Garcia F. Enteroaggregative Escherichia coli pathotype: a genetically heterogeneous emerging foodborne enteropathogen. FEMS Immunol Med Microbiol. 2012;66:281-98.

7. França FLS, Wells TJ, Browning DF, Nogueira RT, Sarges FS, Pereira AC, et al. Genotypic and phenotypic characterisation of enteroaggregative Escherichia coli from children in Rio de Janeiro, Brazil. PLoS One. 2013;8:e69971.

8. Gerritsen J, Smidt H, Rijkers GT, de Vos WM. Intestinal microbiota in human health and disease: the impact of probiotics. Genes Nutr. 2011;6:209-40.

9. Harrington SM, Strauman MC, Abe CM, Nataro JP. Aggregative adherence fimbriae contribute to the inflammatory response of epithelial cells infected with enteroaggregative Escherichia coli. Cell Microbiol. 2005;7:1565-78.

10. Hicks S, Candy DC, Phillips AD. Adhesion of enteroaggregative Escherichia coli to pediatric intestinal mucosa in vitro. Infect Immun. 1996;64:4751-60.

11. Jensen BH, Olsen KEP, Struve C, Krogfelt KA, Petersen AM. Epidemiology and clinical manifestations of enteroaggregative Escherichia coli. Clin Microbiol Rev. 2014;27:614-30.
12. Jonsson R, Struve C, Boisen N, Mateiu RV, Santiago AE, Jenssen H, et al. Novel aggregative adherence fimbria variant of enteroaggregative Escherichia coli. Infect Immun. 2015;83:1396-405.

13. Kang G, Pulimood AB, Mathan MM, Mathan VI. Enteroaggregative Escherichia coli infection in a rabbit model. Pathology. 2001;33:341-6.

14. Knutton S, Lloyd DR, McNeish AS. Adhesion of enteropathogenic Escherichia coli to human intestinal enterocytes and cultured human intestinal mucosa. Infect Immun. 1987;55:69-77.

15. Knutton S, Shaw RK, Bhan MK, Smith HR, McConnell MM, Cheasty T, et al. Ability of enteroaggregative Escherichia coli strains to adhere in vitro to human intestinal mucosa. Infect Immun. 1992;60:2083-91.

16. Nataro JP, Scaletsky ICA, Kaper JB, Levine MM, Trabulsi LR. Plasmid-mediated factors conferring diffuse and localized adherence of enteropathogenic Escherichia coli. Infect Immun. 1985;48:378-83.

17. Nataro JP, Kaper JB, Robins-Browne R, Prado V, Vial PA, Levine MM. Pattens of adherence of diarrheagenic Escherichia coli to HEp-2 cells. Pediatr Infect Dis J. 1987;6:829-31.

18. Nataro JP, Hicks S, Phillips AD, Vial PA, Sears CL. T84 cells in culture as a model for enteroaggregative Escherichia coli pathogenesis. Infect Immun. 1996;64:4761-8.

19. Pereira AL, Silva TN, Gomes AC, Araújo AC, Giugliano LG. Diarrhea-associated biofilm formed by enteroaggregative Escherichia coli and aggregative Citrobacter freundii: a consortium mediated by putative F pili. BMC Microbiol. 2010;10:57.

20. Rosa ACP, Mariano AT, Pereira MAS, Tibana A, Gomes TAT, Andrade JRA. Enteropathogenicity markers in Escherichia coli isolated from infants with acute diarrhea and healthy controls in Rio de Janeiro, Brasil. J Med Microbiol. 1998;47:781-90.

21. Schmidt H, Knop C, Franke S, Aleksic S, Heesemann J, Karch H. Development of PCR for screening of enteroaggregative Escherichia coli. J Clin Microbiol. 1995;33:701-5.

22. Tzipori S, Montanaro J, Robins-Browne RM, Vial P, Gibson R, Levine MM. Studies with enteroaggregative Escherichia coli in the gnotobiotic piglet gastroenteritis model. Infect Immun. 1992;60:5302-6.

23. Yamamoto T, Endo S, Yokota T, Echeverria P. Characteristics of adherence of enteroaggregative Escherichia coli to human and animal mucosa. Infect Immun. 1991;59:3722-39. 